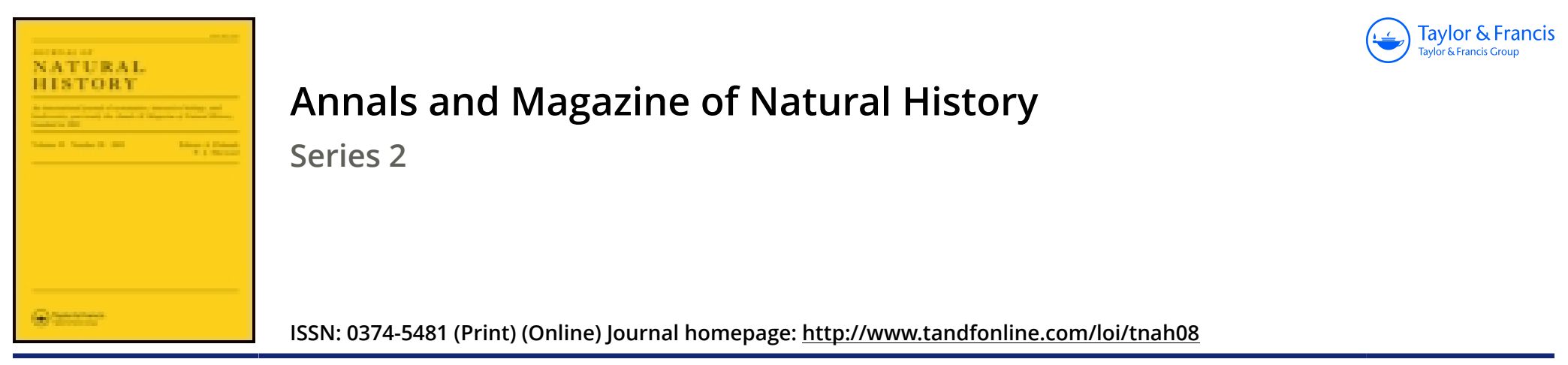

\title{
XLVIII.-On certain Coleopterous insects from the Cape de Verde Islands
}

\section{T. Vernon Wollaston M.A. F.L.S.}

To cite this article: T. Vernon Wollaston M.A. F.L.S. (1857) XLVIII.-On certain Coleopterous insects from the Cape de Verde Islands, Annals and Magazine of Natural History, 20:121, 503-506, DOI: $10.1080 / 00222935708680678$

To link to this article: http://dx.doi.org/10.1080/00222935708680678

$$
\text { Published online: } 26 \text { Oct } 2009 .
$$

Submit your article to this journal $₫$

Џll Article views: 2 


\section{Epëira tubulosa.}

Add the following particulars to the remarks on this species recorded in the catalogue (Ann. and Mag. Nat. Hist. 2nd Series, vol. x. p. 219) :--In December 1856 I received from Mr. R. H. Meade an adult female, which had been captured by Mr. O.P. Cambridge near Blandford in Dorsetshire.

XLVIII.-On certain Coleopterous Insects from the Cape de Verde Islands. By T. Vernon Wollaston, M.A., F.L.S.

THE southern position which the Cape de Verde Islands occupy, with reference to the neighbouring Atlantic groups, renders any contribution towards their fauna of peculiar interest; and it is with much pleasure, therefore, that I am enabled to offer, through the liberality of my friends John Gray, Esq., and the Rev. Hamlet Clark, a few observations on the Coleoptera which they collected at St. Vincent's, during a day's sojourn there (whilst on their passage to Rio Janeiro) in December of 1856.

Considering the excessive barrenness of this the only island at which the mail-steamers touch, on their outward and homeward route, and the short space of time which is allowed for the passengers to go on shore, it will not appear strange that only fifteen species were the result of the combined labours of Messrs. Gray and Clark during the day that they spent at St.Vincent's. Yet, despite the poverty of the place, in an entomological point of view, it is not difficult to gather, even from these few exponents of the Coleopterous world,-if not indeed the general nature of its insect population, at any rate the important fact, that the preponderance which the Heteromera possess (as might, however, be anticipated), over all the other sections of the order, in this sterile spot, is quite extraordinary. Thus, of the fifteen species alluded to, whilst as many as eight are Hetero: merous, only two belong to the Geodephaga, and but one to each of the great divisions Brachelytra, Necrophaga, Cordylocerata; Priocerata, and Rhynchophora.

The two representatives of the Geodephaga are Cicindela littoralis, Fab. (an insect of Mediterranean latitudes, occurring both in the south of Europe and the north of Africa), and an Amblystomus, which may perhaps* be peculiar to these islands, and

* I say "perhaps," because the species which form the subject of the paper, by Erichson, above alluded to, are professedly from Angola. Nevertheless I am assured by Dr. Schaum of Berlin, that the collector who amassed the materials from which Erichson's memoir was compiled, stopped at the Cape de Verdes, on his passage to the African coast; and that, as 


\section{Mr. T. V. Wollaston on certain Coleopterous Insects}

which appears to agree sufficiently well with the deseription of the Hispalis viridulus, given by Erichson in the ninth volume of Wiegmann's 'Archiv für Naturgeschichte,' in 1843. The former of these, the Cicindela, I am told by Mr. Clark, was abundant in a salt locality, or marsh, immediately behind the 'Valley of Death' (so called from its having been the burial-place of the unfortunate sufferer's from the cholera during the fearful visitation of 1855); whilst the Amblystomus occurred amongst the light soil around the roots of a small succulent plant (probably either a Sedum or a Mesembryanthemum),--much in the same manner as we often observe the Harpali to congregate along the seashores in England; and where they were most likely secreted on account of the little shade and moisture which such a position would naturally afford them.

The cxponent of the Brachelytra is a solitary example of an Isomalus, Erichs.,_evidently a new species, which may be thus briefly characterized :-

\section{Isomalus Hesperidum.}

I. niger, nitidus, glaberrimus, valde depressus, ubique subtilissime alutaceus sed fere impunctatus; capite magno, plano; prothorace cordato, postice fortiter angustato, lateribus vix pone medium leviter excavatis, dentem obtusum efficientibus, in dorso latissime longitudinaliter depresso, antice intra angulos anteriores utrinque leviter notato ; elytris prothorace paulo longioribus, punctulo discali impressis; antennis fuscis, basi pedibusque piceis.

Long. corp. lin. $2 \frac{1}{3}$.

I believe that it was detected by Mr. Gray, but I have no note as to the precise circumstances of its capture.

The section Necrophaga is represented by what I conceive to be the Dermestes lupinus, Esch.,- a species liable to be introduced almost everywhere, and therefore well nigh cosmopolitan.

The exponent of the Cordylocerata is a very distinct and elegant Saprinus, the S. equestris of Erichson (Klug's Jahrb. d. Ins. S. 175; and Wiegm. Archiv, ix. 226. 43),-captured by Mr. Clark, near the sea-beach, in stercore humano.

The section Priocerata is shadowed forth by a single Elater, which, I am informed by Mr. Janson, may possibly belong to the genus Monocrepidius, but which is probably new as regards the species. It may be described thus :-

he shortly afterwards died, the insects of the two localities were unfortunately mixed up together; and Erichson, who was not aware that he had touched at those islands at all, described the whole of them as coming from Angola. Thus an amount of confusion has been caused, which can only be dissipated by an accurate knowledge of the Coleopterous faunas of the two regions. 


\section{Monocrepidius? Grayii.}

$M$. linearis, fusco-niger, pilis brevibus cinereis depressis ubique dense vestitus; prothorace convexo, creberrime subtilissimeque punctulato punctulisque majoribus undique crebre obsito; elytris subpunctato-striatis, interstitiis vix puuctulatis ; antemnis, palpis (longiusculis) pedibusque laete rufo-ferrugineis.

Long. corp. lin. 6 .

It was found beneath a stone on one of the highest points of the island; and I have much pleasure in dedicating it to my friend John Gray, Esq., to whose kindness I am shortly about to be indebted for the opportunity of investigating, under the best of auspices, the various portions of the Canarian Group.

The representative of the Rhynchophlor a is a curious insect allied to (though scarcely, I think, identical with) Brashytarsus, of which there is a solitary specimen; and it is worthy of remark that it appears to coincide, even as regards the species, with one taken by Mr. Clark at Blidah, in Algeria, duriug the previous June of the same year.

$\Lambda$ nd, lastly, with respect to the Heteromera above referred to, the eight spccies are as follows:

1. A very beautiful, but variable, Phuleria, with a black dorsal patch behind the middle (and common to both) of its elytra; in some examples of which the patch is so largeiy developed as to cover the entire surface of the elytra, except the shoulders and extreme lateral margin. I would thus characterize it:-

\section{Phaleria Clarkii.}

1. ovata, ferruginea ; capite plus minus infuscato; prothorace transverso-subquadrato, basi utrinque foveola brevi longitudinaliter impresso ; coleopteris læte testaceis, maculn magna discali sublunata nigra vix pone medium ornatis.

Var. $\beta$. Prothoracis disco elytrorumque regione scutellari ac sutura (una cum macula discali) plus minus suffuse nigrescentibus.

$\operatorname{Var} . \gamma$. Capite, prothoracis disco, elytrisque (humeris et limbo pallidiore exceptis) nigrescentibus.

Long. corp. lin. $2 \frac{1}{2}-3$.

It was discovered by Messrs. Gray and Clark (to the latter of whom I have dedicated the species) sub stercore humano, on the sea-beach; having buried itself in considerable numbers, at some distance below the excrement,-in the same manner as is the case with the Phalerice (when under such circumstances) generally.

2. A small insect allied to Cerandria, Dej., but generically distinct from it.

3. The common Opatrum fuscum, Hbst,-so universal in Ann. \& Mag. N. Hist. Ser. 2, Vol. xx. Suppl. 
Mediterranean latitudes, and which occurs also in Madeira and the Canarian Group.

4. A rather large insect, intermediate apparently between Opatrum and Asida, of which I have not been able as yet to determine the genus; but which (as it would seem to be abundant in those islands) is probably well known.

5. An insect, which may perhaps constitute a new genus, bearing some slight prima-facie resemblance to a Pedinus; but with much slenderer legs, distinctly clubbed antennæ, a brownish piceous hue, and a somewhat pubescent surface.

6 and $\%$. Two species of Oxyura, Sol. (= Melancrus, Dej.),probably the $O$. hegeteroides and pedinoides of Erichson, described in Wicgmann's 'Archiv' (ix. 236, 64 and 65), amongst the supposed Coleoptera of Angola.

8. The Hegeter clongatus, Oliv. (=striatus, Latr.), an abundant insect in Madeira and the Canary Islands, which M. Deyrolle of Paris informs me that he has received, also, from Senegal, on the opposite coast of Africa ; and which, moreover, has even been admitted (though I cannot but believe erroneously) into the European Catalogues.

Such are the 15 species collected by Messrs. Gray and Clark during a day's hard work in this barren island. And I can only add that their investigations, for so short a visit, may be considered as eminently successful; for I am informed by my nephew, F. W. Hutton, Esq, of the 23rd Welsh Fusiliers, who lately touched at St. Vincent's on his route to India, and who, likewise, went on shore for a day, to obtain for me all that he was able, that he only "succeeded in capturing six species of beetles, sundry locusts, and a lizard ;" and he further adds the somewhat significant remark, that " a grave-stone sticking out of the middle of the Atlantic would be a paradise compared to it."

XLIX.-Remarks on the Columbinæ, with a Description of a new Indian Pigeon, akin to the 'Stock Dove' of Europe. By EDWand BLYTrF*.

IN no other group of birds is the difficulty of discriminating between species and permanent varieties, whatever latitude may be allowed under either denomination, so great and so constantly recurring, as in sundry genera of Pigeons. And yet each race, however slightly distinguished from certain other races, is remarkably true to its particular distinctive characters, wheresoever it be found; and it remains to show that any gradations

* From the Journal of the Asiatic Society of Bengal, No. 3, 1857. 